\title{
Spaces of Exception and Spaces of Normality: Towards a Relational Understanding of Violence and Peace in Muslim Mindanao
}

\author{
Jeroen Adam
}

\begin{abstract}
This article argues for a relational and historical understanding of the violent conflict in Muslim Mindanao, the Philippines that goes beyond treating this region as a violent "space of exception," but instead points at similarities and congruities with other parts of the Philippines. The consequences of this observation are discussed in relation to the ongoing peace negotiations in the region. Rather than seeing these as efforts potentially transforming Muslim Mindanao into a peaceful "space of normality," it is argued that the impact of these negotiations will remain confined, as they solely tackle the national conflict scale and remain confined to only one type of armed organization.
\end{abstract}

Keywords Philippines, Moro Islamic Liberation Front (MILF), peace negotiations, violent conflict, state formation, Mindanao

\section{Introduction}

That violence and conflict are symptoms of the failure of any normal economic development and well-functioning liberal democracy might look like common sense to most people. However, as a range of scholars have pointed out over the past ten to fifteen years, this view might analytically not be the most productive one. The constant stress on "failures" in conflict regions-failed state, failed governance, failed development, etc.- is above all a normative assessment that is of little help in understanding some of the socio-political and economic transformations at play. Apart from this observation, there are also other, even deeper issues at stake here. As argued by Cramer, a view of conflict as "development in reverse" ultimately rests on the false assumption that conflicts need to be understood as a form of pre-modern barbarism. This barbarism is then contrasted with those places understood as modern, stable, and peaceful. Importantly, as indicated by Cramer, war and violence in this regard becomes 
an idea that invokes "an anxious border" wherein war and violence represent "a territory over the border from civilisation" (Cramer 2006, 27-28). What we see here thus emerging is a representation of war and violence as dysfunctional "spaces of exception" that are then contrasted with a "space of normality," presumably characterized by stable economic growth and functioning liberaldemocratic institutions. In other words, what Cramer's analysis forces us to question is the specific regressive quality that is being ascribed to violent conflict and to take a more critical stance against what ultimately becomes defined as war or violent conflict. Evidently, it logically follows from this analysis that the separation between war/exceptionalism on the one hand and peace/normality on the other is never as absolute as one would imagine. Albeit with some nuances, a similar critique on the representation of violent conflict as a pre-modern space of exception have been made over the past two decades by a range of scholars such as David Keen (2007) and Mark Duffield (2001). For instance, Keen (2007, 11) suggests focusing on the many similarities and continuities between war and peace, rather than seeing these as two separate, radically opposed spheres.

This critique is applied to Muslim Mindanao throughout this article. The above mentioned literature sees the contrast between war/exceptionalism versus peace/normality as one that is translated through a dichotomy between a rational, modern West versus a pre-modern non-West. This binary framing, however, does not by definition have to follow this post-colonial logic. For instance, within the Philippines, a border is constantly being drawn between Muslim Mindanao as an exceptional space of violent conflict versus the rest of the Philippines. An indication of this demarcation can be found in the recent establishment of a conflict monitoring database by the World Bank and International Alert (International Alert 2014). As argued below, the establishment of this database has greatly enhanced our understanding of the complex and multi-scalar character of the violence in the region. In the meantime, however, this database rests on the implicit assumption that conflict and violence only need to be monitored in the administrative region of what is known as the Autonomous Region of Muslim Mindanao (ARMM) and not elsewhere. Albeit in an indirect manner, this database hereby reinforces the image of a border between Muslim Mindanao as a conflict region versus the rest of the Philippines. One only needs to bring to mind the ongoing, brutal war on drugs by the current Duterte administration to understand that this supposedly neat border between war and peace is more complex than generally perceived.

Apart from a critical stance towards the establishment of these borders delimiting exceptionality and normality, the afore mentioned literature also demands attention for the particular qualities ascribed to these exceptional places. As an indication about the manner Muslim Mindanao tends be represented, we will briefly point at two issues here. First, a particular representation exists of Muslim Mindanao as being defined by a feudal pre-modernity. As an illustration 
of this trend, it is useful to refer to the discussion on rido or clan conflict in the region (Torres 2007a). Simply put, it is hereby argued that clan conflict is a defining cultural trait of Muslim Mindanao when compared to other parts of the Philippines. As further argued below, the observation that violence in the region cannot just be explained by pointing at a vertical conflict between Muslim armed groups versus the Philippine state was a crucial and necessary one. Yet, what is most interesting here is the specific cultural framing of this issue. As McCoy (1993) points out, the issue of family and inter-family competition has always been a defining characteristic of the political history of the post-colonial Philippine nation-state. As such, there is nothing culturally specific about the prominence of clan/family in Muslim Mindanao. Next, with this rido discussion, a particular culturalist language has entered the debate. This can already be evidenced by the constant stress on the word rido, a word derived from the Maguindanao language, and as such not applicable to other parts of the Philippines. Even the common English translation of rido as clan conflict is revealing in this regard. While McCoy (1993) still used the term 'family' to describe dynamics of violence and political competition in the Philippines as well as Muslim Mindanao, the much more pejorative term "clan" has now entered the lexicon. Clan is hereby not only understood as a feudal and pre-modern form of political organization, but also contains a particular coercive and violent connotation.

A second representation of Muslim Mindanao-supposedly revealing its uniqueness in contrast to the rest of the Philippines-is the systematic stress on the "stateless" character of this region. As argued by Adam and Van den Boer (2015), a picture is hereby not only painted of a region marked by violent conflict but also weak state institutions. More importantly, a claim is being made about Muslim Mindanao as a region marked by a distinct cultural and pre-modern identity wherein formal state institutions are met with indifference and even outright hostility. In spite of this powerful narrative, detailed empirical research has illustrated how this framing of the region as marked by statelessness is blatantly wrong as state institutions and elected officials remain central in a range of governance issues (Verbrugge, Adam, and Van den Boer 2014; Adam and Van den Boer 2015).

In opposition to this problematic but dominant representation of Muslim Mindanao as a space of exception within the Philippine nation-state, in the following section I argue for a more historical and relational understanding of violence and conflict in the region. Specific emphasis will hereby be put on the many similarities and continuities this conflict ecology has with a broader history of (violent) state formation in the Philippines. In the second part of this article, I then discuss the consequences of this historical and relational approach for our understanding of the current peace negotiations between the Moro Islamic Liberation Front (MILF) and the Philippine government. Finally, it is argued how a successful conclusion of these peace negotiations would have a positive, yet 
confined impact on the overall peace and security situation.

\section{A Relational and Historical Approach to Conflict in Muslim Mindanao}

Muslim Mindanao is facing one of the longest and most protracted conflicts in the world. Although it is always difficult to put a definitive date on the actual beginning of this conflict, it is clear that by the late 1960s Muslim and Christian armed militias started clashing with each other. It was ultimately out of these Muslim militias that the first Muslim rebel group emerged in 1972, the Moro National Liberation Front (MNLF). The start of the MNLF was also one of the main reasons why President Marcos declared martial law in 1972, thereby starting a so-called all-out war against the Muslim minority population in the South. Albeit in different waves of intensity, one witnesses regular peaks of high-intensity violence resulting in numerous deaths continuing to the present. As the region has thus been confronted with substantial violence for almost half a century, it logically follows that this conflict has gone through many transformations over the decades; all of which cannot be touched upon within this article. For the purposes of this article, we would like to stress two transformations that are crucial for a better understanding of the current conflict landscape.

First, various societal fault lines have been integrated within an ever more complex conflict ecology. These fault lines include-amongst others-inter- and intra-Muslim tensions and discussions about indigenous people's rights and ancestral domain. As a result, the master narrative, which pits Muslim armed groups fighting the Philippine state for autonomy/separatism, has become a grave oversimplification. A simple differentiation that helps to make sense of this complexity is to make a distinction between a national vertical conflict versus a sub-national horizontal conflict. The vertical dimension hereby consists of Muslim armed groups against the Philippine state, fighting for autonomy/ independence; the sub-national horizontal dimension consists of violence emerging from a wide range of sub-national tensions. Importantly, different quantitative and qualitative analyses have demonstrated how in recent history a large majority of the violence in Muslim Mindanao emerges from sub-national disputes rather than warfare between Muslim rebel groups and the Philippine army. The first major quantitative study in this respect was conducted by the American NGO The Asia Foundation and first published in 2007 (Torres 2007b). This analysis demonstrates how local elections and tensions over land access are at the root of the majority of violent incidents in the region. As a consequence, the master narrative through which the conflict in Mindanao is still being framed as one of a Muslim minority versus a Christian dominated Philippine nation-state needs to be nuanced as a wide variety of identity labels and social fault lines come 
into play (Adam 2013). In follow-up studies, these findings have been further refined in an elaborate quantitative analysis funded by the World Bank called "The Bangsamoro Conflict Monitoring System" (International Alert 2014). Within this database, a diverse range of conflict data are being collected. Particularly relevant for our argument here is that what is being labelled as "political issues" or national vertical conflict between armed insurgents and the Philippine army which accounts for rougly 25 percent of all violent incidents between 2012 and 2014. Also interesting is that within this 25 percent, violence between the MILF and the Philippine army constitutes only a very small portion and this has further significantly declined since the signing of the Framework Agreement on the Bangsamoro (FAB) in 2012. The most important, immediate causes of violence are tensions over access to the informal economy, including drugs, weapons, and, most importantly, the informal land market. The last important observation that can be noted, based on this research project, is the significant increase in violent incidents in the lead-up to elections, in particular regional and local elections.

A second important issue, and one that is closely related with the observation discussed above, is the large diversity in armed actors operating in the region, of which the MILF is only one. Importantly, the MILF still needs to be understood as the largest and most important organization representing and expressing different grievances of the Muslim community in the Philippines. Moreover, by any account, they still can avail a formidable fighting force in the form of the Bangsamoro Islamic Armed Fighters (BIAF), although it needs to be mentioned that estimates on the size of the BIAF vary greatly. In general, estimates on the number on permanent fighters are put somewhere between 10,000 and 15,000 (Abuza 2005; Podder 2012). However, as explained below, the definition of a "MILF fighter" varies. Apart from the MILF/BIAF, other armed organizations include the Bangsamoro Independence Freedom Fighters (BIFF) which claims to continue fighting for a truly independent Muslim homeland. There is also the well-known terrorist outfit Abu Sayyaf operating particularly on the island of Basilan and hardly present on mainland Mindanao. Lastly, there still exists a range of units and commanders belonging to the MNLF who, despite the official implementation of the final peace agreement in 1996, maintain a considerable fighting force in dispersed areas. A display of this fighting force was witnessed in September 2013 when one faction of the MNLF under the leadership of Nur Misuari invaded the city of Zamboanga, only to retreat after two weeks. Importantly, apart from the "regular" non-state rebel organizations, there also exists a wide range of paramilitary groups, private armies, and state sanctioned security forces. Although less noticed by outside observers, these armed groups maintain a central place in the conflict landscape in the region. In many cases, they stand under direct control of local politicians, appointing the members of these organizations and providing them with necessary resources. In most cases, these different coercive organizations are deployed in highly 
personalized tensions between politicians and their respective clans. It is here that the aforementioned importance of so-called subnational conflicts needs to be situated. When discussing electoral violence, these types of organizations are often mobilized during competition over access to the informal economy or different land disputes. Importantly, roles and identities tend to be overlapping in a sense that being part of a paramilitary group/clan-based coercive organization does not necessarily exclude a role as an MILF and MNLF fighter. Instead, what we are seeing is that an existing coercive capacity is deployed under different denominators and in different scales of conflict and violence. The coercive capacity deployed within these disputes does not just exist outside the statein the form of rebel groups-but is also inasmuch situated within the Philippine state through the strategic use of police forces and paramilitary groupings.

These observations about the multi-layered nature of conflict in the region and the diversity of state and non-state organizations involved have many consequences. As indicated, this serves as a necessary warning against those accounts downplaying the conflict in Mindanao simply as one of Muslim armed groups fighting the Philippine state. Equally important is that this demands a reinterpretation of the place of Muslim Mindanao in the broader history of the Philippines. As argued in the introduction, we hereby warn against those representations approaching Muslim Mindanao as a "space of exception" when compared to the rest of the Philippines. Within this view, Muslim Mindanao is approached as a "conflict region" that is then contrasted with the rest of the Philippines, which-for the ease of the argument-is understood as a nonconflict place of "normality." Without any doubt, there exists a distinctive religious identity and history in Muslim Mindanao when compared to the rest of the Philippines. Also, the history of armed groups fighting for autonomy/ independence is exceptional when compared with other parts of the country. Yet, the historical process of state formation-and all the aberrations, tensions, and violence emerging from this process-bears remarkable similarities with the rest of the Philippines. Analyzing these similarities, instead of constantly focusing on the "exceptionality" of the region is fundamental for a nuanced understanding of everyday dynamics of violence and conflict.

As illustrated by a range of authors (Hutchcroft 2000; Hedman and Sidel 2000), state formation in the Philippines has always been historically mediated through local political elites whom in return for guaranteeing stability were granted a high degree of autonomy. Despite formal centralization, political power hereby has always been devolved, resulting in some sort of de facto decentralization. This became particularly visible with the advent of American colonialism in the Philippines from the late nineteenth century onwards. Instead of opting for the build-up of a centralized bureaucracy, preference was given to a strategy of state formation wherein diverse administrative functions were put under the control of the local executive. This strategy of "benevolent assimilation" 
(Hutchcroft 2000, 277) was inextricably linked with the installment of limited franchise wherein a small group of male, landowning elites were allowed to vote, hereby further cementing their elite status in the locality. A crucial point here is that these elites gained control over a wide range of administrative powers and also came to embody the symbolic capital associated with modern statehood. In the words of Hedman and Sidel $(2000,39)$, this led to the emergence of a process of state formation "distinguished by the subordination of a weakly insulated bureaucracy (including the police) to elected local and national politicians."

Albeit with some variations, this colonial strategy of pacification by limited franchise and through local centers of authority was also implemented in Muslim Mindanao. In contrast to the rest of the country, Mindanao was put under the direct control of the American army which established the Moro Province from 1900 until 1914. The entrance of the United States in Mindanao intensified state building efforts and provoked fierce, often violent, resistance by parts of the Muslim population (Che Man 1990). The answer of the American colonial authorities to this opposition consisted of a mix of harsh suppression and consultation wherein, gradually, coercion made room for more subtle strategies geared towards incorporation in the colonial body-politic. Crucial herein was the deliberate creation of what McKenna $(1998,88)$ provocatively has called a "collaborationist elite" wherein parts of the Muslim nobility became closely involved in colonial administration. Within these embryonic state structures in the Mindanao "frontier," traditional Muslim authorities would henceforth assume a crucial position as gatekeepers and as guarantors of colonial statehood. This newly acquired state authority allowed this emerging Muslim elite network to position themselves in a strategic, pivotal position between the American colonial authorities and ordinary Muslims. As a result, one saw the emergence of enclaves of political control, very similar to the type of "local political fiefdoms" (Anderson $1988,12)$ in other parts of the country.

This colonial process of state formation wherein local strongman in the periphery maintained a great degree of autonomy vis-à-vis the center has largely been maintained in the post-colonial era. As indicated by scholars such as McCoy (1993) and Anderson (1988), one saw the emergence of a true cacique (bosses) democracy wherein oligarchs rooted their authority in the periphery while simultaneously maintaining vital links to Manila through patronage networks in a model of mass democracy. There was no difference in the case of Muslim Mindanao where Muslim leaders were integrated in a nascent national mass democracy through alliances with national-level powerbrokers entrenched in national political parties (McKenna 1998, 6). At least during the first few decades after independence, the legitimacy of the Philippine nation-state was hardly questioned and Muslim Mindanao instead was marked by a relatively high degree of stability. It was not until the promulgation of martial law and the increasing influx of Christian settlers that this stability was called into question and large- 
scale violence erupted in Muslim Mindanao. As indicated by the Philippine historian Patricio Abinales $(2000,109)$, the strategy of Marcos hereby consisted of breaking a "delicate balance between state and strongman by creating his own network of local allies, less autonomous and more beholden to him, whom he then unleashed on his enemies." Subsequently, large parts of Mindanao were confronted with a high-intensity all-out war between the MNLF and the Philippine army. The dominant image that one gets is that the Marcos regime was intent on "crushing" the Muslim armed groups and the Muslim population in general through brute force. To a certain extent this is true. In particular, the period between 1972 and 1976 was one of harsh military confrontation and deliberate killings of Muslim civilians in an attempt to violently crush the rebellion. Due to the brutal nature of this campaign, support for the MNLF increased significantly and prominent clan leaders, whom at the initial stage remained hesitant to support the MNLF, openly pledged their allegiance to the rebellion.

Yet, this narrative of open confrontation overlooks the many subtleties which surrounded the specific counterinsurgency strategy of the Marcos regime. Marcos remained an expert in patrimonial politics and alternative, often very personalized, networks were being built between Marcos/Manila and elites in Mindanao, including Muslim elites which in return wielded almost absolute and highly repressive authority in the locality (Abinales 2010, 159). In still a later stage throughout the 1980s, former rebel leaders and sympathizers of the MNLF were lured into state appointed positions which were deliberately created for socalled "returnees" (Molloy 1988). In this regard, the Marcos policy bears some similarities with the American colonial strategy in the sense that a subtle mix was being used wherein brutal coercion and integration went hand in hand.

Contrary to the genuine attempts at reaching substantial democratization in Philippine society after the fall of Marcos in 1986, this system of mediated state formation relying on local strongman-politicians remained largely untouched. As illustrated by Verbrugge and Adam (2016), the decentralization law of 1991 and the increase in financial resources for the local executive at the barangay (village) and municipal level through a system of internal revenue allotment increased the stakes for rebel/commanders to become involved in local elections. As such, the local state increasingly became a structure of accumulation, but these commander-politicians also became tied to Manila through a system of patronage which was not the case before. These vertically organized patronage networks, which are intimately tied up with party politics, are an important instrument in the hands of national-level politicians to retain a degree of control over their local-level counterparts.

An extreme example of this was the rise of the Ampatuan clan throughout the 2000's in Muslim Mindanao, which signified the high time of quasiauthoritarian rule in the region. The family patriarch Andal Ampatuan Sr. acted 
as governor of the province of Maguindanao from 2001 until 2009, while his son, Zaldy Ampatuan, was the regional governor of the ARMM from 2005 until 2009. In addition, different municipalities and barangays were governed by members of the Ampatuan clan. Rather tellingly, a report published by Human Rights Watch (2010) was entitled "They own the people" indicating how the Ampatuan clan not only gained absolute control over the institutional machinery of the Philippine state at the regional level, but also how this political control translated into a real reign of terror marked by high levels of violence and human rights violations. The most terrifying example of this strongman rule was displayed in 2009 when fiftyeight people were brutally murdered when an opposition candidate attempted to register to compete in the elections for the governorship in the province of Maguindanao. Crucial for our understanding about the rise of the Ampatuan clan in Muslim Mindanao, however, are the vital links that were being maintained with the sitting administration in Manila at the time. Those areas controlled by the Ampatuan were hereby acting as vote banks for the sitting administration in Manila. In return, the clan was allowed quasi-authoritarian rule at the regional level (Rood 2012).

Touching upon the emergence of the Ampatuan clan brings us to another crucial point and this concerns the high level of control over coercive organizations by the local executive. Once again, this goes back to the very preliminary colonial projects of state formation in the Philippines. As indicated, these were organized through a strategy of limited franchise wherein the local executive was acting as a proxy of the center in Manila. A crucial component of this strategy of mediated state formation is the high level of control by the local executive over different types of coercive organizations. Above all, local politicians at the municipal level obtained control over the appointment of local police (Hutchcroft 2000). This system, which has been maintained until today, explains the very close alliances that exist between policing and local politicians. Apart from these vital linkages, there exists a long tradition of establishing auxiliary or paramilitary forces in attempts to quell different armed opposition movements. Among the first examples are the establishment of so-called Civilian Guards against Communist rebels in Luzon throughout the 1940s and 1950s. Under the Marcos regime, the so-called Civilian Home Defense Forces (CHDF) were put in place to deal with different armed rebellions, including the MNLF. The CHDF was then strategically deployed by a set of local politicians and strongman acting as proxies of the Marcos regime. A notable example was the rise of Mohamed Ali Dimaporo in Lanao throughout the 1970s and 1980s (Bentley 1993). At a later stage, the CHDF was formally disbanded in 1987 by the new Aquino administration and replaced by so-called Civilian Armed Forces Geographical Unit (CAFGU). Although technically under the control of the AFP, different units of the CAFGU receive living allowances from local politicians and even private companies. As a result, they often came to act as the private armed 
forces of these local strongman. Apart from the CAFGU, the Civilian Voluntary Organizations (CVO) also acted as proxies of the Philippine National Police, but stood under firm control of local politicians at the municipal and barangay level. As a result, the CVO are regularly deployed by local politicians during electoral campaigns to harass political rivals and are also actively used to fight armed oppositionist movements such as the MILF and the MNLF (Center for Humanitarian Dialogue 2011). This illustrates once again that these paramilitary organizations were deployed by the Ampatuan clan both to fight the MILF and rival politicians. As described by Hedman and Sidel $(2000,58)$, this historical tradition of paramilitary organizations "served to blur the lines between state/ society, civil/military, military/para-military, and legal/illegal, with a variety of peculiar coercive formations-notably so-called 'lost commands', 'private armies' and 'fanatical sects'-operating at the behest of entrenched local 'warlords' and landed oligarchs." Above all, this wide set of coercive paramilitary organizations have become an inextricable part of a broader process of competitive elections and democratization in Muslim Mindanao as well as in other places in the Philippines.

\section{Peace Negotiations and the Return to Normality?}

As is clear from our explanation above, it is essential to contextualize the history of Muslim Mindanao in the wider history of the Philippine nation-state as many of the violent dynamics we are witnessing in Muslim Mindanao bear resemblance with other parts of the Philippines. In the second part of this article, let us discuss the impact this renewed relational and historical approach has for our understanding of the ongoing peace negotiations between the government of the Philippines and the MILF. However, before we can delve into this discussion, some necessary background to these negotiations is first provided.

As explained, the MILF is an armed rebel group or revolutionary organization (depending on one's viewpoint) waging a struggle for an autonomous Bangsamoro homeland. The presence of the MILF is particularly situated on mainland Mindanao and the MILF can be considered the most important and bestorganized mass organization expressing the historical grievances of the Muslim minority in the Philippines. Upon the start of the Aquino presidency in 2010, it was one of the main objectives of the new administration to reach a final peace agreement with the MILF. This policy was most welcomed by the leadership of the MILF, indicating they saw little future in continuing a pointless armed struggle against a superior enemy that has been going on for decades. With the publicly stated willingness of the two parties to reach a final peace agreement, the Philippine government and the MILF started an intensive round of negotiations aiming to conclude a final peace agreement before the end of the Aquino 
presidency in 2016. Importantly, these talks built further upon a process that was already initiated in 1997 when a set of mechanisms were gradually set up which were meant to improve communication between the Armed Forces of the Philippines and the MILF, signaling a delicate ceasefire between both parties that was regularly interrupted with periods of intense armed confrontation.

Although the whole process of rapprochement between the MILF and the Philippine government has thus far been a slow and frustrating one with major setbacks, a first serious attempt to reach a final peace agreement was made in 2008 when the Memorandum of Agreement on Ancestral Domain (MoA-AD) was deliberated. Unfortunately, shortly before the signing of the document, the Supreme Court of the Philippines ruled that different components of the agreement were unconstitutional and negotiations were aborted. However, by 2010 with the beginning of the Aquino administration and building further on the failed MoA-AD document, an optimistic feeling existed that finally the time was ripe for reaching a final conclusion in a decades-long and tiring war. Learning from past mistakes and with a strong involvement of a range of international organizations acting as third party monitors, considerable gains were quickly made. Already in 2012, the FAB was signed; a largely symbolic document serving as the basis for further and more specific deliberation. One of the most important statements in the FAB was the formal commitment to replace the existing ARMM with the Bangsamoro (Moro/Muslim nation) and that the Bangsamoro would be governed by a Bangsamoro Basic Law (BBL). The FAB served as the foundational document for the Comprehensive Agreement on the Bangsamoro (CAB) which was signed in 2014 and included four additional annexes on power sharing, normalization, revenue generation and wealth sharing, and finally on transitional arrangements and modalities. Spanning ninety-one pages, this document stipulated, among other things, the terms under which an autonomous Bangsamoro region would be established, mechanisms for demobilization, disarmament and reintegration of MILF fighters, provisions for transitional justice, and modes of revenue generation.

By any account, the $\mathrm{CAB}$, which was meant to serve as the blueprint for the final Bangsamoro Basic Law (BBL), was a major achievement and the overall mood was one of optimism and hope. The BBL was finally released by the Bangsmoro Transition Commission in September 2014 after which it was meant to be ratified by the Philippine Congress and Senate. Yet, very quickly, the BBL became subject to close scrutiny and public debate. While the stance on the part of the MILF was that the major features of the BBL were nonnegotiable, multiple questions were quickly raised about the constitutionality of some of the major provisions. One of the most heated discussions for instance concerned the provisions that foresaw the establishment of a Bangsamoro police, consisting of demobilized MILF fighters, supposedly independent from the Philippine National Police (OPAPP 2015). In short, while the negotiations resulting in the 
BBL were the outcome of a consultation between a limited set of actors eager to reach an agreement, major hurdles appeared when this bill was subject to a wider audience.

In the ongoing political debates about the implementation of the BBL, a major blow occurred in the most unexpected manner on January 25, 2015. This unforeseen event was an ill-fated intervention by one highly trained unit of the Philippine National Police, the Special Action Force (SAF), in search of two suspected terrorists in the municipality of Mamasapano in January 2015. As this intervention was not coordinated with the MILF, this SAF unit ran into the camps of the MILF and the BIFF, resulting in an armed clash which killed fortyfour SAF police officers, eighteen MILF, five BIFF fighters, and five civilians. This incident caused a major shift in public opinion. While before the position of the majority of politicians was one of ignorance and disinterest, the Mamasapano massacre turned the public mood into one of overt hostility against the MILF and the BBL. To many, the whole event was understood as the ultimate proof of the untrustworthiness of the MILF as they were hiding suspected terrorists and killing Philippine police officers. Although an independent commission (Board of Inquiry 2015) later published a report showing terrorists were not hiding in MILF camps and despite the many public statements by the MILF expressing their willingness to help search for one escaped terrorist, the event proved to be a major blow for the whole peace process. Ultimately, an increasing number of Philippine politicians were no longer willing to stick out their necks for the signing of the BBL or even out right rejected the whole endeavor. Quite symbolically, the sessions within the Philippine Senate on the BBL did not manage to reach the necessary quorum to continue the discussion. What thus started as a hopeful and ambitious endeavor ultimately ended in huge disappointment and frustration, in particular within Muslim Mindanao and from the side of the MILF. If there is, however, one positive side to this story, it is that the MILF did not resume open warfare but further pledged its commitment to continue the peace process. It was hereby decided to await the presidential elections and start working with the new administration. After the May 9, 2016 presidential elections, the new president of the Philippines turned out to be the rather controversial candidate Duterte. As with a number of issues with this new administration, it remains to be seen which steps will be taken in the near future to continue the peace process and how far the peace agreement will be effectuated into an actual law.

For many, including the MILF, the unforeseen Mamasapano massacre stands as the prime cause for the failure in concluding the BBL. However, just looking at this single event risks missing some crucial features of the complex peace and conflict landscape in Mindanao. As such, based on our call for a more historical and relational understanding, one has to put these negotiations into a broader perspective. A first crucial observation is that peace negotiations had already been going on for a very long time. Indeed, the conflict in Muslim 
Mindanao is one of the longest in the world. However, the alternative story that is missing in this rather depressing string of events is that, for most of this time, the Philippine government has been in constant negotiation and deliberation with Muslim armed groups. Already in 1976, a first peace agreement was being signed between the MNLF and the Philippine government called the Tripoli Agreement. Subsequently, through a painstakingly slow process, this Tripoli Agreement has been implemented into law, leading in 1989 to the establishment of the ARMM and in 1996 to a final peace agreement after which the leader of the MNLF, Nur Misuari, was appointed as governor of the ARMM (Bertrand 2000). Already one year later in 1997, the first preliminary talks on installing a basic ceasefire mechanism were started with the MILF, which by then had taken over the role of the main representative of the Muslim population fighting for autonomy. In other words, as long as there has been conflict in the region, there also exists a counter history of peace negotiations. This observation serves as further proof that the post-colonial history of Muslim Mindanao cannot just be understood as being one of eternal confrontation with Manila, but is equally one of constant deliberation and integration. It is obvious that the recent rapprochement between the MILF and the Philippine government needs to be understood within this longer-term perspective. Yet, there are also a number discomforting observations to this insight.

First, there is the mere observation that despite this very long history of peace negotiations, the region still has not reached something that approximates a truly sustainable and positive peace. Tellingly, the high hopes that were put on the finalization of a peace agreement with the MNLF and resulting in the establishment of the ARMM have failed to deliver upon their promises. Secondly, with every process of negotiation, a further fragmentation of Muslim armed groups has occurred. In fact, the MILF itself is a split-off from the MNLF and this division needs to be explained by the huge disappointments engendered by the Tripoli Agreement among large parts of the Muslim population in Mindanao. Also in the lead-up to the signing of the BBL, a split-off occurred within the MILF as the BIFF under the leadership of commander Umbra Katho decided to continue waging full-scale war against the Philippine state. A third observation concerns the transformations that have occurred over the decades and which we have discussed in the first part of this article. Put simply, these transformations have resulted in a complex conflict ecology that cannot just be tackled by classic peace negotiations between a rebel group and the Philippine government. As a whole range of subnational tensions have entered this complex ecology which go beyond this national scale, it is evident that even in the case of a successful conclusion of the peace negotiations, these subnational tensions will remain a factor of instability. Evidently, this is also the case with the wide range of coercive organizations beyond classic rebel groups that have entered the conflict theatre. These organizations which often are situated in a grey zone between a formal and 
informal illegality have become an indispensable part of the conflict landscape. As illustrated, these organizations exist all over the Philippines. However, in the case of Muslim Mindanao, these different types of coercive organizations interact and ultimately reinforce each other. While in some cases, men are being deployed as MILF or MNLF fighters, these same MILF or MNLF fighters can also become involved in localized tensions wherein the allegiance is foremost to a set of local elites and violence is conducted through a paramilitary organization in the name of clan loyalty.

As long as we are confronted with a socio-political landscape wherein coercion remains a central feature, the idea that classic, national peace negotiations will manage to put an abrupt halt to all this is wishful thinking. For people closely following the situation in Muslim Mindanao, this is hardly surprising. When discussing the potential impact of the successful conclusion of the peace talks with the MILF with members of NGOs actively engaged in this process, one is sometimes surprised by the very humble expectations these people have in relation to these negotiations. Interestingly, these private humble expectations stand in sharp contrast to the public statements predicting a new phase of hope, stability, and peace once the peace negotiations are finalized. In other words, the specific relational reading of the conflict landscape in Mindanao warns against those accounts which put too high hopes on formal peace negotiations such as the still ongoing negotiations with the MILF. The objective is hereby not necessarily to paint an overtly pessimistic picture. Clearly, the successful conclusion of the peace talks would be a considerable step forward, albeit only one step among many others. Next, throughout the years, many NGOs and organizations working in the region have deliberately opted for a two-track approach in their peacebuilding strategy; providing support for the nationallevel negotiations while simultaneously being engaged in different types of locallevel conflict management interventions such as attempting to settle or reconcile the diversity of local-level violence plaguing the region. By any account, it is extremely important that the peace negotiations with the MILF succeed, if only to avoid the resumption of armed hostilities between the MILF and the Philippine army which would be a disaster for the peace and security situation in the region.

\section{Conclusion}

In this article, we have attempted to put the ongoing peace negotiations between the MILF and the Philippine government within a broader historical and relational perspective. Two central arguments have hereby been put forward. First, the conflict landscape in Mindanao is constituted by a wide range of coercive organizations deployed in different scales of conflict. Within this variety of organizations, the MILF is only but one, albeit a very important one. This 
diversity in coercive organizations is deeply rooted in a multilayered conflict landscape of which the classic struggle of Muslim rebels fighting a Christian dominated Philippine nation-state is but one of these many layers. Although this vertical, national dimension of the conflict landscape remains beyond any doubt important, different qualitative and quantitative analyses have illustrated how the causes of most of the violent incidents are much more local and parochial in nature. Second, we have attempted to sketch how these characteristics of the broader conflict ecology in Muslim Mindanao cannot be conceptualized as aberrations when compared with other parts of the Philippines. Instead, a long national history of mediated state formation through local strongmen/politicians in the periphery and the crucial control of these local strongmen/politicians over a wide range of coercive organizations are crucial to understanding the complex ecology in Muslim Mindanao as well as in many other places of the country. It has been illustrated how Muslim Mindanao cannot be approached as a "space of exception" when compared to other parts of the Philippines. Although there might be a quantitative difference in the intensity of violent incidents in Muslim Mindanao, our short historical overview shows how violence and control over coercion has always been at the heart of colonial and post-colonial state formation all over the Philippines.

What do these two observations teach us about the impact of the ongoing peace negotiations between the MILF and the Philippine government? First of all, this article serves as a warning not to understand these negotiations-in the case they are successfully implemented-as a process inevitably culminating in a sustainable and positive peace in the region, hereby installing a new "space of normality." A successful conclusion of the peace accords between the MILF and the Philippine government will without any doubt have a positive impact on the overall peace and security situation. At the same time, it needs to be acknowledged that this impact will remain limited. Full-scale warfare between the Philippine army and other rebel groups such as Abu Sayyaf and the BIFF will most likely continue or even intensify. Many of the paramilitary organizations roaming around in the region will remain. Moreover, despite different clauses on normalization and disarmament of MILF fighters in the BBL, the enormous amount of weaponry that has flooded the region over the past several decades will not all of a sudden disappear. On the other hand, this somewhat pessimistic or realistic view of the peace process represents a very confined understanding of this peace agreement as one merely resulting in the cessation of armed hostilities between the MILF and the Philippine Armed Forces. As indicated, this is by and large already the case, and therefore this potential outcome might even not be that important. What is much more important is the way the BBL will structurally impact how state formation, governance, and democracy overall are being organized in the region. In other words, for the BBL to have a true and lasting impact, we need to conceptualize the BBL as a political document, 
hopefully enhancing the overall quality of governance in the region, thereby enabling a less coercive and elitist type of state formation, as has historically happened. Clearly, it is too early to assess the impact of the BBL. At the moment, the BBL is still subject to public and political debate and it still remains to be seen to what extent the BBL as it stands now will be modified before being implemented under the Duterte administration. However, what can already be stated-and organizations such as the MILF and the majority of the population in Muslim Mindanao are perfectly aware of this-is that the success or failure of the BBL will not be assessed through its capacity of installing a cessation of armed encounters between the MILF and the AFP. Instead, the real challenge for many people in Muslim Mindanao is much broader in a sense that the true ambition and outcome of the BBL should be to install a less coercive, more transparent, less elitist type of governance in the region, thus enhancing and deepening the process of true democratization.

\section{References}

Abinales, Patricio N. 2000. Making Mindanao. Cotabato and Davao in the formation of the Philippine Nation-State. Manila: Ateneo de Manila University Press.

Abinales, Patricio N. 2010. Orthodoxy and History in the Muslim-Mindanao Narrative. Manila: Ateneo de Manila University Press.

Abuza, Zachary. 2005. “The Moro Islamic Liberation Front at 20. State of the Revolution." Studies in Conflict \& Terrorism 28 (6): 453-479.

Adam, Jeroen. 2013. "A comparative analysis of the micro-level genealogies of conflict in the Philippines' Mindanao Island and Indonesia’s Ambon Island." Oxford Development Studies 41 (2): 155-172.

Adam, Jeroen, and Dorien vanden Boer. 2015. "Conflict mediation and traditional authority in the province of Lanao del Sur, Mindanao." London School of Economics, JSRP Paper 26, August 2015. http://www.lse.ac.uk/internationalDevelopment/ research/JSRP/downloads/JSRP26.AdamEtAl.pdf (accessed April 14, 2017).

Anderson, Benedict. 1988. "Cacique Democracy in the Philippines: Origins and Dreams." New Left Review 169: 3-34.

Bentley, Carter G. 1993. "Mohamad Ali Dimaporo: A Modern Maranao Datu." In An Anarchy of Families: State and Society in the Philippines, ed. Alfred W. McCoy, 243285. Madison: University of Wisconsin Press.

Bertrand, Jacques. 2000. "Peace and Conflict in the Southern Philippines. Why the 1996 Peace Agreement is Fragile." Pacific Affairs 73 (1): 37-54.

Board of Inquiry. 2015. The Mamasapano Report. Manila: Philippine National Police. http://newsinfo.inquirer.net/678685/full-report-the-mamasapano-incident (accessed April 14, 2017)

Center for Humanitarian Dialogue. 2011. Armed Violence in Mindanao. Militia and Private Armies. Geneva: Center for Humanitarian Dialogue and The Institute of Bangsamoro Studies. 
Che Man, W.K. 1990. Muslim Separatism. The Moros of Southern Philippines and the Malays of Thailand. Oxford: Oxford University Press.

Cramer, Christopher. 2006. Civil War is not a Stupid Thing. Accounting for Violence in Developing Countries. London: Hurst \& Company.

Duffield, Mark. 2001. Global Governance and the New Wars. The Merging of Development and Security. London: Zed Books.

Hedman, Eva Lotta, and John Sidel. 2000. Philippine Politics and Society in the Twentieth Century: Colonial legacies, post-colonial trajectories. London/New York: Routledge.

Human Rights Watch. 2010. "They Own the People" The Ampatuans, State-Backed Militias, and Killings in the Southern Philippines. New York: Human Rights Watch.

Hutchcroft, Paul D. 2000. "Colonial Masters, National Politicos, and Provincial Lords: Central Authority and Local Autonomy in the American Philippines, 1900-1913." The Journal of Asian Studies 59 (2): 277-306.

International Alert. 2014. Rebellion, Political Violence and Shadow Crimes in the Bangsamoro. The Bangsamoro Conflict Monitoring System (BCMS), 2011-2013. Washington: The World Bank. http://www.bcms-philippines.info/ (accessed april 14, 2017).

Keen, David. 2007. Complex Emergencies. London: Polity Press.

McKenna, Thomas M. 1998. Muslim Rulers and Rebels. Everyday Politics and Armed Separatism in the Southern Philippines. Jackson: University of California Press.

McCoy, Alfred, R. Anderson Sutton, Thongchai Winichakul, and Kenneth M. George. 1993. An Anarchy of Families. State and Family in the Philippines. Madison: University of Wisconsin Press.

Molloy, Ivan. 1988. "The Decline of the Moro National Liberation Front in the Southern Philippines." Journal of Contemporary Asia 18 (1): 59-76.

OPAPP (Office of the President of the Philippines). 2015. "Bangsamoro not separate from PNP.” March 7. http://archive.peace.gov.ph/milf/news/bangsamoro-police-notseparate-pnp (accessed December 8, 2016).

Podder, Sukanya. 2012. "Legitimacy, Loyalty and Civilian Support for the Moro Islamic Liberation Front. Changing Dynamics in Mindanao.” Politics, Religion \& Ideology 13 (4): 495-512.

Rood, Steven. 2012. “Interlocking Autonomy: Manila and Muslim Mindanao." In Autonomy and Armed Separatism in South and Southeast Asia, ed. Michelle Miller. Singapore: Institute for Southeast Asian Studies.

Torres, Wilfredo M. 2007a. "Introduction." In Rido: Clan Feuding and Conflict Management in Mindanao, ed. Wilfredo Magno Torres III, 11-36. Manila: The Asia Foundation.

Torres, Wilfredo M. 2007b. Rido: Clan Feuding and Conflict Management in Mindanao. Makati City: The Asia Foundation.

Verbrugge, Boris, Jeroen Adam, and Dorien vanden Boer. 2014. "Hybrid Systems of Conflict Management and Community-Level Efforts to Improve Local Security in Mindanao." London School of Economics, JSRP Paper 13, March. http:// www.lse.ac.uk/internationalDevelopment/research/JSRP/downloads/JSRP13. AdamVerbruggeBoer.pdf (accessed April 14, 2017).

Verbrugge, Boris and Jeroen Adam. 2016. "Questioning the State-Rebel divide in Mindanao? A Comparative Analysis of North Cotabato and Compostela Valley Province." Asian Journal of Social Science 44 (1): 247-287. 


\section{Jeroen Adam}

Jeroen Adam is an assistant professor at the Department of Conflict and Development Studies, Ghent University, Belgium. His research focuses on dynamics of violent conflict, natural resource access and legal pluralism in Southeast Asia, more in particular the Philippines and Indonesia.

Submitted: September 9, 2016; Revised: December 15, 2016; Accepted: February 13, 2017 